\title{
Short Communication: Adoption level of indigenous communities on agricultural technology in
East Kalimantan, Indonesia: Problem and adaptive solutions
}

\author{
NDAN IMANG \\ Faculty of Agriculture, Universitas Mulawarman. Jl. Ki Hajar Dewantara, Gunung Kelua, Samarinda 75123, East Kalimantan, Indonesia. \\ Tel.+62-541-201275, Fax.: +62-541-206407, •email: imangndan15@gmail.com,imang_ndan@yahoo.co.id \\ Center for Social Forestry (CSF), Faculty of Agriculture, Universitas Mulawarman. J1. Ki Hajar Dewantara, Gunung Kelua, Samarinda 75123, East \\ Kalimantan, Indonesia
}

Manuscript received: 15 October 2019. Revision accepted: 22 February 2020

\begin{abstract}
Imang N. 2020. Short Communication: Adoption level of indigenous communities to agricultural technology: problem and adaptive solutions in East Kalimantan, Indonesia. Biodiversitas 21: 1160-1164. The economic and cultural background of the indigenous people of the Dayak Borneo was traditional shifting cultivation, hunting, and gathering. Since the 1980s, Indonesian central government promoted Resettlement Program by relocating them in down rivers to encourage and to improve their agricultural and economic life. By living in downriver with limited farming areas, they, of course, need more products of agriculture and therefore government promoted agricultural extension. The objectives of the study are to: assess adoption level of two indigenous Dayak communities on agricultural technology, assess the causes of problems on adoption of agricultural technology, and seek adaptive strategy in implementing agricultural technology. Data were collected by interviewing 54 respondents that were selected randomly and descriptive qualitative approach was used for data analysis. Some important findings were: (i) adoption level of 60\% i.e. Low level and $40 \%$ i.e. middle level in both villages; (ii) the low level of adoption was caused by some factors, such as: low performance of the extension officers which was caused by the lack support from government, and the background of the farmers; farmers with low education background need visual media to understand the extension and to see the evidence of the new technology; (iii) adaptive strategies to improve agricultural extension level such as: government should support the extension officers with appropriate visual and material support such as LCD projector, portable generator, appropriate training and communication skill that suitable with sociocultural background of the respondents. The extension officers also need to understand the cultural background of the respondents. Practical implication is that the government can develop more typical effective method of extension for indigenous communities with low educational background and traditional way of agriculture. Theoretical implications, of course, are to provide specific further information for research related to agricultural extension.
\end{abstract}

Keywords: Adoption, agriculture, Dayak, extension, indigenous, Swidden agriculture

\section{INTRODUCTION}

Since the 1980s, Indonesian central government demanded the indigenous people living in remote upper rivers and isolated areas to move downriver through the "resettlement program". One of communities with the largest populations of the Borneo indigenous people is Dayak, with a population of around 500,000 persons (Kueng and Imang, 2007). They were originally living in Kalimantan plateau for hundreds of years. In their ancestor land, they have huge land for traditional farming namely shifting cultivation (locally called ladang), and also have huge virgin forests for hunting, fishing, and gathering. Imang et al (2018) explained that the Indigenous Dayak has around 4-7 plots of land which are equal to 7-20 ha for practicing shifting cultivation (ladang). The purposes of this government program were to relocate the people to more accessible settlement areas in downriver with good access, and government will help them to develop a new settlement or new village for the relocated people. Since then, thousands of indigenous Dayak people moved to the new settlement and merging in one or more larger villages.
After moving down and living near town, they face limited areas for agricultural activities. Some of the new settlements are Pampang Village (formerly part of Sungai Siring Village) and Sungai Bawang Village. However, in the new settlements, they have limited land for farming compared to land they had in their original villages. This situation, of course, demands increasing land productivity by implementing agricultural technology. Compared to neighbor farmers of other ethnics such as the Javanese, Buginese, Sundanese, Imang (2010) found that the Kenyah Dayaks people seem to be left behind in adopting agricultural technology. In order to improve agriculture productivity and to change the behavior of farmers from traditional shifting cultivation to more sustainable and productive agriculture, Indonesian government implemented extension program (Penyuluhan Pertanian). According to Roger and Shoemakers (1971) and supported by Memon et al. (2014), agricultural extension is essentially a message delivery system organized to convey the latest findings of agricultural; research to farmers. Effective communication is, therefore, the prime requirement in extension work (Memon et al. 2014). 
The objectives of the research were: (i) to assess adoption level of agricultural technology by the respondents; (ii) to determine causes and problems to adopt agricultural technology; and (iii) to identify adaptive strategy for implementation of agricultural technology.

\section{MATERIALS AND METHODS}

\section{Study area}

Research was conducted in two urbanized villages of indigenous Kenyah Dayaks people in East Kalimantan, Indonesia, i.e.: Pampang or Budaya Pampang Village (Samarinda City) and Sungai Bawang Village (Kutai Kartanegara District) from June to August 2019.

\section{Procedures}

Data were collected through individual interviews with 27 respondents in Pampang and 27 respondents in Sungai Bawang. Questions were related to some aspects of agricultural technology of rice farming, cocoa, oil palm and vegetable gardens: soil processing, seed treatment, fertilizer, disease and pest control, and weed control. For a better adoption level, we also asked some questions related to the problems on technology adoption from respondents' perspective and from extension officers' perspective. Likert-score was used to quantify the answers and presented on tables and graphics (Likert 1932; Carifio and Perla 2007; Derrick and White 2017). Based on the accumulation of Likert-score, the level of adoption is categorized in three ranks as shown on Table 1 (Likert 1932).

Table 1. Rank and criteria of adoption level

\begin{tabular}{lll}
\hline Score & Adoption level & Criteria \\
\hline $27-44$ & Low & Awareness and interesting \\
$45-63$ & Middle & Evaluation \\
$64-81$ & High & Trial and adoption \\
\hline
\end{tabular}

\section{RESULTS AND DISCUSSION}

\section{Characteristic of respondents}

The indigenous Dayak moved to Pampang and Sungai Bawang in some small groups from 1980s to 1992. The main livelihoods of villagers in the new settlement are farmers of rice, cacao, oil palm, and vegetables, traditional hand-crafts. Average age is 54 years, and majority (87\%) have education level of elementary school and below. Population of each village is around 1907 persons and 1610 persons respectively.

\section{Adoption level}

Adoption level in this study is how far the respondents adopting and practicing agricultural technology, particularly in rice farming, cacao garden, oil palm garden, and vegetable garden.
Table 2. Adoption level to agricultural technology

\begin{tabular}{lll}
\hline \multirow{2}{*}{ Agricultural technology } & \multicolumn{2}{c}{ Score/criteria } \\
\cline { 2 - 3 } & \multicolumn{1}{c}{ Pampang } & $\begin{array}{c}\text { Sungai } \\
\text { Bawang }\end{array}$ \\
\hline Soil treatment & $42 /$ low & $40 /$ low \\
Seed treatment & $53 /$ middle & $55 /$ middle \\
The use of fertilizers & $57 /$ middle & 60/middle \\
Disease and pest control & $54 /$ middle & $53 /$ middle \\
Weed control & $42 /$ low & $40 /$ low \\
\hline
\end{tabular}

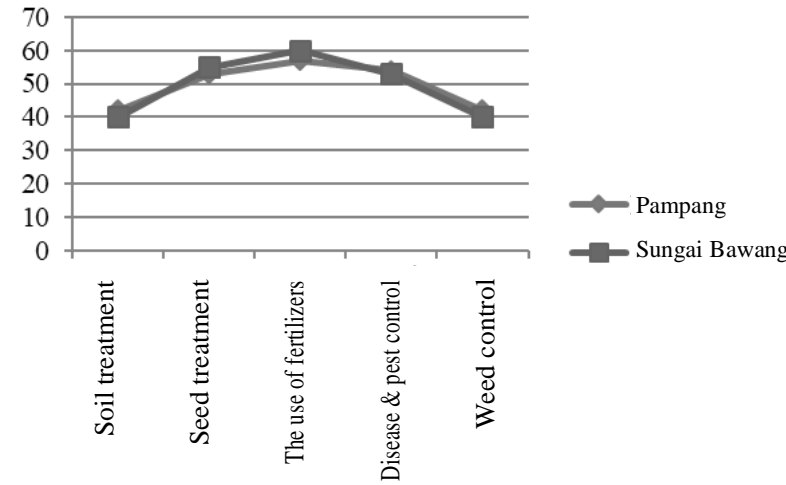

Figure 1. Trend in adoption levels of two villages

Table 2 shows the adoption levels of agricultural technology in Pampang and Sungai Bawang Villages are at $40 \%$ i.e. low level, and at $60 \%$ i.e. middle level. Figure 1 shows two graphs that are very close to each other. It means that their responses are almost similar.

\section{Soil treatment}

Soil treatment is the process in which soil is loosed and made soft using machines, human-power by plowing or animal-power so that sunrise can penetrate deeper to soil, to improve the structure and texture of soil so that it can improve soil fertility. Table 2 shows that adoption level to soil treatment in both villages was low.

Respondents argue that they are not used to plow the soil because this kind of work may cause back pain, and even headaches. They are not used to bow while working for long time. For soil treatment, they usually just remove and burn some small branches. They had experience that the better the burning process, the more fertile the soil. Imang (2010) mentioned the same thing that Kenyah Dayak people in Batu Majang village were also not familiar with hoe to plow their rice field because they are not comfortable with it.

\section{Qualified seed and treatment}

Qualified seed is recommended according to some criteria: for example, rice, $98 \%$ purity of variety, sprout quality of $80 \%$, not expired and treatment was done by submerging seeds in salted water for one hour before planting, and dormancy-break. Table 1 above shows that adoption level of qualified seed was at middle level. At the research sites, some respondents said that they used 
recommended seed but it was not appropriately treated before planting, and some used their own seed from the previous harvest or just bought from any seed seller. Similarly, for cacao and oil palm seeds or seedlings, most respondents used seeds from previous harvest or from other sources. They claimed that there's no clear information from extension officer about the advantages of the certified seeds. So far the farmers were not so concern about the purity of the seed, because they did not know the difference of the product.

\section{Fertilizer}

Fertilizer application functions to improve the growth and strength of plant which is in turn to improve production. Table 2 shows that adoption level to the use of fertilizer is at middle level. Regarding the middle-level of adoption, we identified some responses as follows: respondents used fertilizer only when it was available (mostly given for free through project scheme), some respondents used organic fertilizer (on their own) during the soil treatment/preparation; and some argued that in Swidden agriculture practice, they do not apply fertilizers but the harvest is good as long as the weather or rainfall is enough. Another reason is that the rice is just for subsistence, so that as long as the rice is enough for oneyear consumption, it is regarded as enough. This is an example of traditional knowledge on how to improve soil fertility. Kueng and Imang (2007) found that the Basap Dayak constructed simple terrace using trees in order to prevent soil erosion and to hold the hummus as natural fertilizer.

\section{Disease and pest control}

For pest and weed control, most of the respondents applied pesticide and herbicide that are available in agriculture shop nearby. The respondents also used manual way, for example, to capture and kill grasshopper at night. However, none of the respondents used chemical way for disease control.

\section{Weed control}

The purpose of weed control is to protect and prevent weeds from growing and sprouting whether using manual method or chemical/herbicide. In this case, the respondents mostly used Round up and Gramoxone. This part is to know how respondents follow recommended safe methods of weed control as follows: wearing long-sleeve shirts, working gloves, safety goggles along with long pants as well as covered shoes, and considering wind direction. Table 2 shows that adoption level to safe weed control was at low level. Respondents were not so concerned about the dangers of herbicide to health because the extension officer did not notice the danger of the herbicides. During application of the herbicide, most respondents wore long sleeve shirts and mouth masks, but they didn't wear covered shoes. The respondents were also not concerned with the wind direction that may cause them to inhale herbicides.

\section{Cause of low adoption level}

In order to explore why adoption level to agricultural technology was mostly at low level in both villages, it is important to know the reasons from the respondents' perspective or responses to the performances of extension workers. Concerning the adoption level, Table 3 shows that, in Pampang Village, $70 \%$ of the respondents were at low level and only $30 \%$ at middle level. Similarly, in Sungai Bawang Village, $60 \%$ of respondents was at low level and the rest $40 \%$ at middle level.

Respondent claimed that intensity or frequency of field extension by extension worker was low, only one or three times a year in sporadic way. Respondents expected that extension should be conducted at least once a month with a regular schedule. Respondents also needed field excursion to learn from other successful farmers because they need visual evidence of new technology. Regarding the frequency, Effendy and Hutapea (2010) also suggested that farmers considered extension not effective if the frequency of visits of field officers is only once a month. It was mentioned in Indonesian Law No. 16/2006 regarding Agricultural Extension System that Extension Officers should have capability, skill, and working spirit to improve agricultural development.

Table 3. Response of respondents to extension officer performance

\begin{tabular}{llc}
\hline \multicolumn{1}{c}{ Responses of respondents to extension officers' performance } & \multicolumn{2}{c}{ Score and criteria } \\
\cline { 2 - 3 } Sungai Bawang \\
\hline Intensity of extension & $30 /$ low & $40 /$ low \\
Follow-up of extension & $43 / \mathrm{low}$ & $44 / \mathrm{low}$ \\
Visual tool for extension & $38 / \mathrm{low}$ & $43 / \mathrm{low}$ \\
Media of extension & $51 /$ middle & $49 / \mathrm{middle}$ \\
Communication technic & $44 / \mathrm{low}$ & $47 / \mathrm{middle}$ \\
Demonstrate economic advantages & $43 / \mathrm{low}$ & $44 / \mathrm{low}$ \\
Observability of output & $48 / \mathrm{middle}$ & $47 / \mathrm{middle}$ \\
Complexity of the extension & $60 /$ middle & $57 / \mathrm{middle}$ \\
Trialability & $44 / \mathrm{low}$ & $43 / \mathrm{low}$ \\
Influence of old culture & $40 / \mathrm{low}$ & $39 / \mathrm{low}$ \\
\hline
\end{tabular}


Regarding the method, respondents complain that extension officers do not use visual media for the extension, only oral method so that it was difficult to understand and always boring. Respondents also complain about the complexity to understand the material provided by extension officer. Extension officers neither provide actual examples of the advantages of agricultural technology, hence, respondents with low education find it difficult to adopt the new technology. Respondents expect extension officers to demonstrate every material in a very easy and clear method. An important aspect for the farmers is that the extension officer must convince the farmers about the economic advantages of the new technology through demonstration plot and simple calculation. Regarding the relation between education level and innovation adoption, Warku (2019) found that education level had significant influence on adoption level of tomato production packages. In regard to importance of visual tools for extension activity, Akintunde and Idowu (2019) suggested that the effects of visual tools on access to information had a highly significant positive impact on the use of information and communications technology by extension officers.

\section{Alternative and adaptive solution}

In order to improve the adoption level of the farmers to agricultural extension, it is very important to explore the needs and expectations of the respondents and how Extension Workers should improve their skill and competency for more effective extension services in the future.

Table 4 shows that in order to increase adoption level of agricultural technology by farmers, respondents in Pampang scored high for 5 aspects. Similarly, in neighboring village of Sungai Bawang, respondent also scored high for 6 aspects. It indicates that such aspects should be put on the high priority to improve field extension service in the future. For the indigenous people with low education and background of hunting and gathering and traditional shifting cultivation, an innovativebreakthrough of simple extension and easier to understand method is really needed. Lawal et al. (2019) suggested that the respondents who were mostly educated agreed that knowledge of mathematics/statistics is the most important requirement for data management. Extension officers also need to adjust the method to suit the background of the respondents. Regarding extension method, Oyedeji and Christiana (2019) mentioned that extension officers should use preferred methods by farmers such as farmers visit, home visit, contact farmers and method demonstration.

Table 4 also shows that formal education level of extension officers is not an important factor for respondents to adopt the technology as long as the extension officer can deliver extension in an understandable way. Figure 2 indicates that respondents in the two villages were similar in their responses to extension workers' performance.

\section{Response of extension officers to government support}

The low adoption level is not necessarily caused by low response from the farmers and extension officers, but also because of the lack of government support for extension program. In order to discover necessary support extension officers needed from government, five Extension Officers were interviewed, their responses were presented in Table 5. This table indicates that none of the extension officers is satisfactory with government supports to conduct field extension. They complained because they were not provided with necessary skill or training, field extension facility and future career guarantee. Some of the extension officers were unsatisfied with the prolonged contractual-job with government. They also need future good career for the future. The extension workers also need improved skills through advance training on extension skills. As mentioned above that the respondents need visual tool for extension so that it is easier for farmers to understand. Besides that, the extension workers also need appropriate material or media support for extension activities such as personal computer (laptop) and LCD (Liquid Crystal Display). In order to support the use of the media for example LCD, the extension needs portable generator for field extension. As for information, electricity connection is not available in this area so that portable generator is crucial.

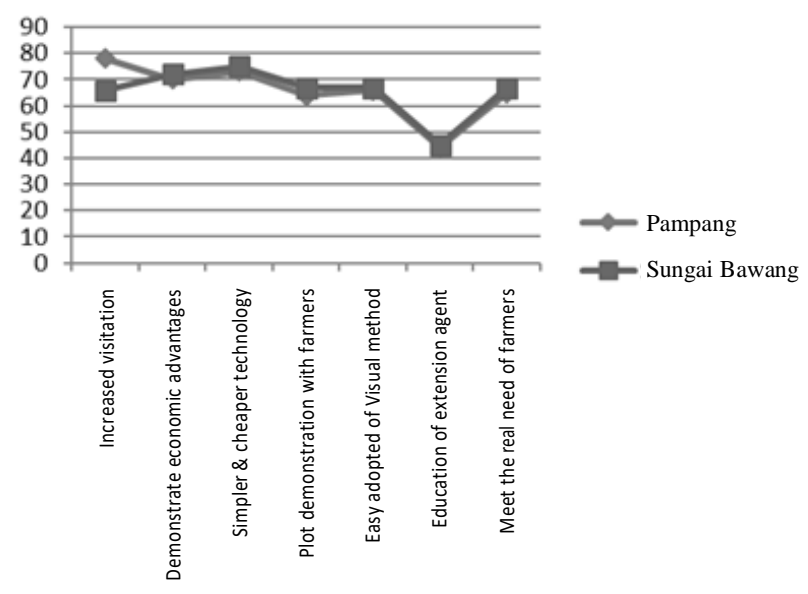

Figure 2. Trend of the respondents' expectations of extension process

Table 4. Expectations of respondents on method of agricultural extension service delivery

\begin{tabular}{lcl}
\hline \multicolumn{1}{c}{ Expectation of respondents } & $\begin{array}{c}\text { Likert- } \\
\text { score }\end{array}$ & Criteria \\
\hline Increased visitation & 78/high & 66/high \\
Demonstrate economic advantages & 70/high & 72/high \\
Simpler and cheaper technology & 73/high & 75/high \\
Plot demonstration with farmers & 64/middle & 67/high \\
Easy adopted of Visual method & 66/high & 67/high \\
Education of extension agent & 44/low & 45/low \\
Meet the real need of farmers & 65/high & 67/high \\
\hline Note: score: $27-45:$ low; 46-64: middle; 65-81: high &
\end{tabular}


Table 5. Government support needed by extension officers

\begin{tabular}{lcl}
\hline \multicolumn{1}{c}{$\begin{array}{c}\text { Government support } \\
\text { for extension officer }\end{array}$} & $\begin{array}{c}\text { Likert- } \\
\text { score }\end{array}$ & \multicolumn{1}{c}{ Criteria } \\
\hline Financial support for field extension & 10 & Fair \\
Technical skill support for improved & 7 & Unsatisfactory \\
extension & 12 & Fair \\
field operational support/motorbike & 11 & Fair \\
Future good career & 7 & Unsatisfactory \\
Material/media support from & & \\
\hline
\end{tabular}

overnment

Note: Likert-score: 5-8: unsatisfactory; 9-12: fair; 13-15: satisfactory

To conclude, adoption levels of most of the respondents in both villages were low and the graphic trends of adoption levels were almost similar among two villages. The low adoption level caused by multiple factors such as low performance of the extension officers, extension couldn't be demonstrated to convince respondents about the advantages of the new technology, old cultural and subsistence background of the respondents. $87 \%$ of respondents with low education levels (Elementary School and even not finishing Elementary School) need comparative-excursion for successful farmers. They need to experience real success other than knowing the theory. On the other hand, the extension officer excused that the low adoption level was also caused by the lack of necessary government support which leads to ineffectiveness practice in field extension; farmers with low educational background need visual media to understand the extension. Another adaptive way to practice agricultural technology is that the extension officer should explore and practice the traditional knowledge and wises that were already familiar to the respondents and use existing local materials.

Practical implication of the study is that the government can develop more effective method of extension for indigenous communities with low educational background and traditional way of agriculture. The Dayak indigenous community of Kalimantan itself is estimated covering more than one million people. Theoretical implications, of course, to provide specific further information for research related to agricultural extension.

\section{ACKNOWLEDGEMENTS}

I would like to express my gratitude to the University of Mulawarman, Samarinda, Indonesia particularly the Faculty of Agriculture for providing small researchincentive for selective lecturers. We would also like to thanks the people of the two villages for their strong support during field survey.

\section{REFERENCES}

Akintunde MAO, Oladele OI. 2019. Use of information communication technologies among Agricultural Extension Officers in Lesotho. J Agric Exten 23 (3): 50-65.

Carifio J, Perla RJ. 2007. Ten common misunderstandings, misconceptions, persistent myths and urban legends about Likert Scales and Likert Response formats and their antidotes. J Soc Sci 3 (3): 106-116.

Derrick B, White P. 2017. Comparing two samples from an Individual Likert Question. Intl J Math Stat 18 (3): 1-13.

Effendy J, Hutapea Y. 2010. Analisis adopsi inovasi pertanian berbasis padi di sumatera selatan dalam perspektif komunikasi. Jurnal Pengkajian dan Pengembangan Teknologi Pertanian 13 (2): DOI: 10.21082/jpptp.v13n2.2010.p\%25p [Indonesian]

Imang N, Rujehan, Duakaju NN. 2018. Assessment of daleh swidden agriculture as an innovative alternative to conventional swidden under conditions of external pressure on local forest management in Kalimantan, Indonesia. Biodiversitas 19: 840-848.

Kueng J, Imang N. 2007. Kajian Kearifan Traditional Suku Punan Basap di Kabupaten Kutai Timur, Indonesia. Universitas Mulawarman, Samarinda. [Indonesian]

Lawal A, Kakara AT, Abdullahi AH, Alhaji AJ. 2019. Data management capabilities of extension personnel in Kaduna Agricultural Development Agency Kaduna State, Nigeria. J Agric Extens 23 (4): 22-29.

Likert R. 1932. A Technique for the measurement of attitudes. Arch Psychol 140: 1-55.

Memon, I., Panhwar, K., Chandio, R., Bhutto, A. Khooharo, A. (2014). Role of mass media in dissemination of agricultural technology among the farmers of Jaffarabad District of Balochistan. J Basic Appl Sci 10: 525-531.

Oyedeji YT, Christiana AO. 2019. Farmers' assessment of the effectiveness of extension communication methods used in Ogbomoso Agricultural Zone of Oyo-State, Nigeria. J Agric Extens 23 (3): 126-134.

Roger EM, Shoemaker FF. 1971. Communication of Innovation: A Crosscultural Approach. $2^{\text {nd }}$ ed. Free Press, New York, USA.

Warku AA. 2019. Factors affecting diffusion and adoption of agricultural innovations among farmers in ethiopia case study of Ormia Regional State Western Sewa. J Med Biol 1(2): 54-66. 